\title{
PEMANFAATAN MIKROALGA SEBAGAI BIOSORBEN PADA PROSES BIOSORPSI LOGAM BERAT
}

\author{
Tiara Wilan \\ Jurusan Teknik Lingkungan, Fakultas Arsitektur Lanskap dan Teknologi Lingkungan, \\ Universitas Trisakti, Jakarta, Indonesia \\ Email korespondensi: tiara08215056@std.trisakti.ac.id
}

\begin{abstract}
ABSTRAK
Industri seperti pelapisan logam dan pertambangan menghasilkan limbah-limbah industri mengandung logam berat yang dapat mencemari lingkungan. Karya ilmiah ini bertujuan untuk memberikan informasi mengenai upaya penanggulangan pencemaran logam berat di perairan dengan metode biosorpsi dengan memanfaatkan mikroalga sebagai sorben. Biosorpsi adalah metode penyisihan logam berat dengan memanfaatkan materi biologis atau mikroba. Salah satu mikroba yang dimanfaatkan untuk proses biosorpsi adalah mikroalga. Proses biosorpsi terjadi pada permukaan sel yaitu dengan metode ion exchange. Mikroalga memiliki beberapa gugus fungsi yang berperan dalam proses ion exchange tersebut. Beberapa hasil penelitian telah membuktikan bahwa mikroalga mampu menyerap logam berat tertentu. Hasil penelitian terdahulu, menyebutkan bahwa mikroalga Chlorella vulgaris memiliki kapasitas adsorpsi untuk logam Zn sebesar 43,41 mg/g. Mikroalga Chlorella miniata mampu menyerap logam $\mathrm{Cr}$ sebesar 41,12 mg/g . Pada sorpsi logam $\mathrm{Cu}$ menggunakan Chlorella sp. didapatkan kapasitas adsorpsi sebesar 33,4 mg/g. Sehingga, mikroalga merupakan salah satu sorben yang berasal dari bahan biologis yang efektif untuk menyerap logam berat sebagai upaya pengendalian pencemaran di lingkungan.
\end{abstract}

Kata Kunci: Biosorpsi, Mikroalga, Logam Berat

\section{PENDAHULUAN}

Peningkatan kegiatan industri mengakibatkan meningkatnya pencemaran pada lingkungan. Pada dasarnya, setiap kegiatan industri pasti akan menghasilkan limbah, terutama industri yang bergerak dalam bidang pelapisan logam dan pertambangan. Limbah-limbah hasil industri ini mengandung logam berat yang dapat mencemari lingkungan, mengancam kesehatan manusia, dan ekosistem (Wang dan Chen,. 2009). Beberapa jenis logam berat yang dimaksud menurut adalah, $\mathrm{Hg}, \mathrm{Cr}, \mathrm{Pb}, \mathrm{Zn}, \mathrm{Cu}, \mathrm{Ni}, \mathrm{Cd}, \mathrm{As}, \mathrm{Co}, \mathrm{Sn}$, dan lain-lain.

Beberapa pengolahan dapat dilakukan untuk mengurangi konsentrasi ion logam berat yaitu secara fisika-kimia dan biologi. Secara fisik-kimia, Mishra,. dkk (2016) menjelaskan bahwa metode yang paling sering digunakan untuk menyisihkan logam berat dari perairan yaitu presipitasi kimia, koagulan lime, ion exchange, reverse osmosis dan solvent extraction. Metode fisik-kimia memiliki kelemahan yaitu biaya yang tinggi, memakan energy yang banyak, dan kurang efektif saat konsentrasi logam berat dikisaran 10-100 mg/L (Mehta dan Gaur, 2005). Maka dari itu, pengolahan secara biologi dengan memanfaatkan mikroba dapat menjadi teknologi alternatif untuk mengurangi masalah tersebut dengan kelebihan bahwa metode ini dapat menyisihkan logam berat $<10 \mathrm{mg} / \mathrm{L}$. Dalam Peraturan Menteri Lingkungan Hidup Republik Indonesia Nomor 5 Tahun 2014 Tentang Baku Mutu Air Limbah, pada industri pelapisan logam dan galvanis, kadar logam $\mathrm{Cu}$ dan $\mathrm{Cr}$ yang diperbolehkan hanya sebesar 0,5 $\mathrm{mg} / \mathrm{L}, \mathrm{Zn}$ sebesar $1 \mathrm{mg} / \mathrm{L}$, Ni dan $\mathrm{Pb}$ sebesar $0,1 \mathrm{mg} / \mathrm{L}$.

Biosorpsi dapat diartikan sebagai proses adsorpsi yang memanfaatkan mikroorganisme sebagai sorben. Beberapa mikroba yang dapat dimanfaatkan antara lain yaitu bakteri, alga, dan jamur (Kumar dkk, 2014 ; Murphy dkk, 2007). Alga memiliki polisakarida, protein atau lipid pada dinding sel yang mengandung beberapa gugus fungsi seperti amino, hidroksil, karboksil dan sulfat yang dapat berperan sebagai tempat pertukaran ion logam (Deng,. dkk, 2007). Beberapa jenis mikroalga telah digunakan dalam proses sorpsi, seperti penelitian yang dilakukan oleh Al-Rub dkk., (2006) menggunakan Chlorella vulgaris untuk proses sorpsi $\mathrm{Cu}$, dan sorpsi logam $\mathrm{Pb}, \mathrm{Cd}$, dan $\mathrm{Hg}$ oleh Spirulina dalam penelitian yang dilakukan oleh Chojnacka dkk., (2005).

Tujuan dari karya ilmiah ini yaitu untuk memberi informasi beberapa upaya penyisihan logam berat dengan memanfaatkan mikroalga. 


\section{TINJAUAN PUSTAKA}

\section{Pencemaran Logam Berat}

Pencemaran logam berat telah menjadi permasalahan global dikarenakan tingkat toksisitas yang tinggi, bioakumulasi yang tinggi pada tubuh manusia dan rantai makanan, sulit terdegradasi di alam, dan terkadang bersifat karsinogenik pada manusia (He dan Chen,. 2014). Pb, Hg, $\mathrm{Cr}$, $\mathrm{Ar}, \mathrm{Cd}, \mathrm{Zn}$, dan $\mathrm{Cu}$ adalah beberapa contoh logam berat yang paling sering ditemukan di air limbah buangan hasil industri. Lone,. dkk (2008) menjelaskan, Cr biasa dihasilkan dari limbah electroplating, tekstil, dan industri kulit; $\mathrm{Cu}$ biasa dihasilkan dari limbah electroplating, industri plastic dan industri emisi; Cd dihasilkan dari plastik, pestisida dan polivinil; Hg biasa dihasilkan dari emisi industri penghasil caustic soda, thermometer dan industri pembuat lampu; Sedangkan $\mathrm{Zn}$ biasa dihasilkan dari industri karet dan cat.

Beberapa contoh efek negatif jika kelebihan logam berat $\mathrm{Cr}$ pada kesehatan manusia yaitu seperti dermatitis, muntah-muntah, diare, kerusakan liver, dan alergi kulit (Rangabhasiyam dan Selvaraju, 2015). Salah satu contoh negatif dari logam berat Ar yaitu kanker dan diabetes (Iriel,. dkk 2015). Menurut Widayatno, dkk (2017), kehadiran logam berat Pb yang konsentrasinya berlebih di perairan dapat masuk kedalam tubuh manusia dan menyebabkan pertumbuhan tubuh yang terhambat, penurunan kecerdasan anak, hingga kelumpuhan. Pada lingkungan perairan, konsentrasi logam berat pada sedimen lebih tinggi dari konsentrasi logam dalam air dimana sedimen ini merupakan substrat yang dapat mempengaruhi kehidupan organisme yang hidup didalamnya (Fachrul, dkk 2011).

\section{Biosorpsi}

Salah satu metode untuk menyisihkan logam berat adalam metode sorpsi/adsorpsi. Menurut Pratiwi dan Prinajati, (2018), adsorpsi merupakan suatu proses dimana molekul suatu larutan berinteraksi dengan permukaan suatu zat padat. Metode adsorpsi adalah salah satu metode yang prosesnya sederhana, dapat didaur ulang, dan biayanya relative murah. Dalam proses adsorpsi, terdapat 2 jenis yaitu adsorpsi fisika dan adsorpsi kimia. Adsorpsi fisika terjadi karena gaya Van der Walls dimana ketika gaya tarik molekul antara larutan dan permukaan media lebih besar daripada gaya tarik substansi terlarut dan larutan, maka substansi terlarut akan diadsorpsi oleh permukaan media. Sedangkan adsorpsi kimia terjadi ketika terbentuknya ikatan kimia antara substansi terlarut dalam larutan dengan molekul dalam media.

Biosoprsi adalah suatu proses adsorpsi dimana terjadi interaksi dan pembentukan dari ion kompleks antara ion dari logam berat dan gugus fungsi dari dinding sel mikroba (Bayramoğlu, dkk 2006). Biosorpsi juga dapat disebut sebagai proses adsorpsi dengan menggunakan mkroba sebagai sorben. Biosorben dapat diartikan sebagai sorben yang berasal dari materi biologis yang digunakan untuk menyisihkan logam berat.

Mikroalga adalah salah satu contoh dari berbagai biosorben yang dapat digunakan dalam proses biosorpsi. Mikroalga mempunyai waktu generasi yang sangat cepat. Oleh karena itu dalam waktu yang relatif singkat, perbanyak sel akan terjadi secara cepat, terutama jika terjadinya cahaya dan sumber energi yang cukup. Beberapa spesies mikroalga dapat menyisihkan logam berat diatas angka 90\% (Shanab,. dkk 2012). Beberapa jenis mikroalga telah banyak dimanfaatkan sebagai biosorben untuk menyisihkan logam berat di perairan.

Tabel 1. Hasil Penelitian Biosorpsi Logam Berat oleh Mikroalga

\begin{tabular}{|c|c|c|}
\hline Judul Paper, tahun & Penulis & Hasil Penelitian \\
\hline $\begin{array}{l}\text { Bioremoval capacity of } \\
\text { three heavy metals by } \\
\text { some microalgae species } \\
\text { (Egyptian Isolates), } 2012\end{array}$ & $\begin{array}{l}\text { Shanab S, Essa A, Shalaby } \\
\text { E }\end{array}$ & $\begin{array}{l}\text { - Sorpsi logam } \mathrm{Cd} \text { dan } \mathrm{Pb} \text { menggunakan } \\
\text { Pseudochlorococcum typicum } \\
\text { - Logam } \mathrm{Cd} \text { yang terserap sebesar } 5,48 \mathrm{mg} / \mathrm{g} \\
\text { dan logam } \mathrm{Pb} \text { yang terserap sebesar } 4,49 \\
\mathrm{mg} / \mathrm{g}\end{array}$ \\
\hline $\begin{array}{l}\text { Biosorption of copper and } \\
\text { zinc by immobilised and } \\
\text { free algal biomass, and the } \\
\text { effects of metal } \\
\text { biosorption on the growth }\end{array}$ & $\begin{array}{l}\text { Wan Maznah W.O, Al- } \\
\text { Fawwaz A.T, Surif M. }\end{array}$ & $\begin{array}{l}\text { - Sorpsi logam } \mathrm{Cu} \text { dan } \mathrm{Zn} \text { menggunakan } \\
\text { Chlorella sp. } \\
\text { - Logam } \mathrm{Cu} \text { yang terserap sebesar } 33,4 \mathrm{mg} / \mathrm{g} \\
\text { dan logam } \mathrm{Zn} \text { sebesar } 28,5 \mathrm{mg} / \mathrm{g}\end{array}$ \\
\hline
\end{tabular}


and cellular structure of

Chlorella sp. and

Chlamydomonas $s p$.

isolated from rivers in

Penang, Malaysia, 2012

Adsorption of $\mathrm{Ni}^{2+}$,

$\mathrm{Zn}^{2+}$ and $\mathrm{Pb}^{2+}$ onto dry Ferreira L S, Rodrigues M $\mathrm{S}$, de Carvalho J C M,

- Sorpsi logam Zn menggunakan Chlorella biomass of Arthrospira (Spirulina) platensis Lodi A, Finocchio E, vulgaris

and Chlorella vulgaris. I.

Perego P, Converti A

- Logam Zn yang terserap sebesar $43,41 \mathrm{mg} / \mathrm{g}$

Single metal systems, 2011

\begin{tabular}{|c|c|c|}
\hline $\begin{array}{l}\text { Surface complexation } \\
\text { mechanism and modeling } \\
\text { in Cr(III) biosorption by } \\
\text { a microalgal isolate, } \\
\text { Chlorella miniata, } 2006\end{array}$ & $\begin{array}{l}\text { Han X, Wong Y S, Tam } \\
\text { N F Y }\end{array}$ & $\begin{array}{l}\text { - Sorpsi logam } \mathrm{Cr} \text { menggunakan Chlorella } \\
\text { miniata } \\
\text { - Logam Cr yang terserap sebesar } 41,12 \mathrm{mg} / \mathrm{g} \\
\text { pada pH } 4,5\end{array}$ \\
\hline $\begin{array}{l}\text { Trace element removal by } \\
\text { Spirulina sp. from copper } \\
\text { smelter and refinery } \\
\text { effluents, } 2004\end{array}$ & $\begin{array}{l}\text { Chojnacka K, Chojnacki } \\
\text { A, Gorecka H }\end{array}$ & $\begin{array}{l}\text { - Sorpsi logam Hg dengan Spirulina } s p \text {. } \\
\text { - Logam Hg yang terserap sebesar } 1,4 \mathrm{mg} / \mathrm{g}\end{array}$ \\
\hline
\end{tabular}

\section{PENUTUP}

Dari hasil karya ilmiah diatas, dapat disimpulkan bahwa mikroalga merupakan biosorben yang baik dalam menyisihkan pencemaran logam berat diperairan. Berbagai jenis mikroalga telah terbukti mampu menyerap logam berat tertentu dengan kapasitas adsorpsi yang berbedabeda. Sehingga, perlu dilakukan penelitian lebih lanjut mengenai kemampuan mikroalga untuk menyisihkan logam berat karena kemampuan dari setiap jenis mikroalga berbeda-beda dalam menyisihkan logam berat.

\section{DAFTAR PUSTAKA}

Al-Rub, F.A.A, El-Naas, M.H., Anshour, I., Al-Marzouqi, M. 2006. Biosorption of copper on Chlorella vulgaris from single, binary and ternary metal aqueous solutions.

Process Biochemistry. $41: 457-464$.

DOI:10.1016/j.procbio.2005.07.018

Bayramoglu, G., Tuzun, I., Celik, G. 2006. Biosorption of mercury(II), cadmium(II) and lead(II) ions from aqueous system by microalgae Chlamydomonas reinhardtii immobilized in alginate beads.

Int. J. Miner. Process. 81, 35-43.

DOI: $10.1016 /$ j.minpro.2006.06.002

Chojnacka, K., Chojnacki, A., Gorecka, H,. 2004. Trace element removal by Spirulina sp. from copper smelter and refinery effluents.

Hydrometallurgy. 74:147-153

DOI:10.1016/j.hydromet.2003.10.003

Chojnacka, K., Chojnacki, A., Górecka, H., 2005. Biosorption of $\mathrm{Cr}^{3+}, \mathrm{Cd}^{2+}$ and $\mathrm{Cu}^{2+}$ ions by blue-green algae Spirulina sp.: kinetics, equilibrium and the mechanism of the process. Chemosphere. $59: 75-84$.

DOI: $10.1016 /$ j.chemosphere.2004.10.005

Deng, L., Su, Y., Su, H., Wang, X., Zhu, X,. 2007. Sorption and desorption of lead(II) from wastewater by green algae Cladophora fascicularis.

Journal of Hazardous Materials. 143 : 220-225.

DOI:10.1016/j.jhazmat.2006.09.00

Fachrul, M.F., Iswanto, B., Maruthi, D. 2011. Kajian konsentrasi logam berat Timbal (Pb) dan Kadmium (Cd) pada sedimen sungai Donan, Cilacap - Jawa Tengah.

JTL. 5(5) : 145-158.

DOI: http://dx.doi.org/10.25105/urbanenvirotech.v5i5.691 
Ferreira, L.S., Rodrigues, M.S., de Carvalho J.C.M., Lodi, A., Finocchio, E., Perego P., Converti, A. 2011. Adsorption of $\mathrm{Ni}^{2+}, \mathrm{Zn}^{2+}$ and $\mathrm{Pb}^{2+}$ onto dry biomass of Arthrospira (Spirulina) platensis and Chlorella vulgaris. I. Single metal systems.

Chemical Engineering Journal. 173 : 326-333.

DOI:10.1016/j.cej.2011.07.039

Kumar,. R., Sharma, A.K., Singh, P., Dhir, B., Mehta, D., 2014. Potential of Some Fungal and Bacterial Species in Bioremediation of Heavy Metals.

Journal of Nuclear Physics, Material Sciences, Radiation and Applications 1: 213-223.

DOI: 10.15415/jnp.2014.12017

Han, X., Wong, Y.S., Tam, N.F.Y. 2006. Surface complexation mechanism and modeling in $\mathrm{Cr}(\mathrm{III})$ biosorption by a microalgal isolate, Chlorella miniata,

Journal of Colloid and Interface Science. $303: 365-371$.

DOI:10.1016/j.jcis.2006.08.028

He, J., Chen, J.P. 2014. A comprehensive review on biosorption of heavy metals by algal

biomass: Materials,performances, chemistry, and modeling simulation tools.

Bioresource Technology. 160:67-78

DOI: 10.1016/j.biortech.2014.01.068

Iriel, A., Lagorio, M.G., Cirell, A.F. 2015. Biosorption of arsenic from groundwater using Vallisneria gigantea plants. Kinetics, equilibrium and photophysical considerations.

Chemosphere. 138:383-389

DOI: 10.1016/j.chemosphere.2015.06.053

Lone, M.I, He, Z.L., Stoffella, P.J., Yang, X.E. 2008. Phytoremediation of heavy metal polluted soils and water: progresses and perspectives.

J Zhejiang Univ Sci B. 9 : 210-220.

DOI:10.1631/jzus.B0710633

Mehta S K, Gaur J P, 2005. Use of algae for removing heavy metal ions from wastewater: Progress and prospects.

Critical Reviews in Biotechnology. 25(3): 113-152.

DOI: $10.1080 / 07388550500248571$

Mishra, A., Tripathi, B. D., Rai, A. K. 2016. Packed-bed column biosorption of chromium(VI) and nickel(II) onto Fenton modified Hydrilla verticillata dried biomass.

Ecotoxicology and Environmental Safety. 132 : 420-428.

DOI:http://dx.doi.org/10.1016/j.ecoenv.2016.06.026

Murphy, V., Hughes, H., McLoughlin, P., 2007. Cu(II) binding by dried biomass of red, green and brown macroalgae.

Water Research, 41(4): 731-740.

DOI:10.1016/j.watres.2006.11.032

Pratiwi, R., Prinajati, D.P.S. 2018. Adsorption for lead removal by chitosan from shrimp shells. Indonesian Journal of Urban and Environmental Technology. 2(1) : 35-46 DOI : http://dx.doi.org/10.25105/urbanenvirotech.v2i1.3554

Rangabhashiyam, S., Selvaraju, N., 2015. Adsorptive remediation of hexavalent chromium from synthetic wastewater by a natural and $\mathrm{ZnCl}_{2}$. activated Sterculia guttata shell.

J Mol Liq 207:39-49.

DOI:10.1016/j.molliq.2015.03.018

Shanab, S., Essa, A., Shalaby, E. 2012. Bioremoval capacity of three heavy metals by some microalgae species (Egyptian Isolates).

Plant Signaling \& Behavior. 7(3):392-399.

DOI: $10.4161 / \mathrm{psb} .19173$

Wang, J. L., Chen, C. 2009. Biosorbents for heavy metals removal and their future. Biotechnology Advances. 27 : 195-226.

DOI:10.1016/j.biotechadv.2008.11.002

Wan Maznah, W.O., Al-Fawwaz, A.T., Surif, M. 2012. Biosorption of copper and zinc by immobilised and free algal biomass, and the effects of metal biosorption on the growth and 
cellular structure of Chlorella sp. and Chlamydomonas sp. isolated from rivers in Penang, Malaysia.

Journal of Environmental Science. 24(8) : 1386-1393.

DOI: $10.1016 / \mathrm{S} 1001-0742(11) 60931-5$

Widayatno, T., Yuliawati, T., Susilo, A.A. 2017. Adsorpsi logam berat (Pb) dari limbah cair dengan adsorben arang bamboo aktif.

Jurnal Teknologi Bahan Alam. 1(1). 